\title{
Anti-ulcer activity of Ipomoea batatas tubers (sweet potato)
}

\author{
Vandana Panda* and Madhav Sonkamble
}

Department of Pharmacology \& Toxicology, Prin. K. M. Kundnani College of Pharmacy, Jote Joy Building, Rambhau Salgaonkar Marg, Cuffe Parade, Colaba, Mumbai 400005, India

*Corresponding author: Vandana Sanjeev Panda, PhD, Prin. K. M. Kundnani College of Pharmacy, Colaba, Mumbai 400005, India

Submission date: December 30, 2011, Acceptance date: April 31, 2012; Publication date: April 31,2012

\begin{abstract}
Background: Peptic ulcers occur in that part of the gastrointestinal tract which is exposed to gastric acid and pepsin, i.e., the stomach and duodenum. Gastric and duodenal ulcers are common pathologies that may be induced by a variety of factors such as stress, smoking and noxious agents including non-steroidal anti-inflammatory drugs. Ipomoea batatas tubers (sweet potato) contain ample amounts of antioxidants. It has been proven already by many scientific studies that antioxidants have ulcer healing properties. In reference to this, we tried assessing the ulcer healing effect of Ipomoea batatas tubers.
\end{abstract}

Methods: The anti-ulcer activity of the tubers of Ipomoea batatas (sweet potato) was studied in cold stress and aspirin-induced gastric ulcers in Wistar rats. Methanolic extracts of Ipomoea batatas tubers (TE) at two doses, viz., 400 and $800 \mathrm{mg} / \mathrm{kg}$ were evaluated in cold stress and aspirin-induced gastric ulcer models using cimetidine and omeprazole respectively as standards. The standard drugs and the test drugs were administered orally for 7 days in the cold stress model and for 1 day in the aspirin-induced gastric ulcer model. Gastroprotective potential, status of the antioxidant enzymes \{superoxide dismutase (SOD), catalase (CAT), glutathione peroxidase (GPx) and glutathione reductase(GR)\} along with GSH, and lipid peroxidation were studied in both models.

Results: The results of the present study showed that TE possessed gastroprotective activity as evidenced by its significant inhibition of mean ulcer score and ulcer index and a marked increase in GSH, SOD, CAT, GPx, and GR levels and reduction in lipid peroxidation in a dose dependant manner.

Conclusion: The present experimental findings suggest that tubers of Ipomoea batatas may be useful for treating peptic ulcers.

Key Words: Sweet potato tubers, cold stress, aspirin, ulcer, antioxidants. 


\section{BACKGROUND:}

Peptic ulcers, also known as 'ulcus pepticum' are ulcers which occur in that part of the gastrointestine which is exposed to gastric acid and pepsin, i.e., the stomach and duodenum. However, the etiology of peptic ulcers is not clearly known. It results probably due to an imbalance between the aggressive (acid, pepsin and H.pylori) and the defensive (gastric mucus and bicarbonate secretion, prostaglandin, nitric oxide, and innate resistance of mucosal cells) factors [1].

Complications of acute and subacute peptic ulcers usually heal without leaving any visible scar. However, healing of chronic and visible and deeper ulcers may result in complications such as obstruction, haemorrhage and perforations [2].

In a gastric ulcer, generally, the acid secretion is normal or low. In a duodenal ulcer, acid secretion is high in half of the patients but normal in the rest. Gastric and duodenal ulcers are common pathologies that may be induced by a variety of factors such as stress, smoking, nutritional deficiencies and noxious agents including non-steroidal anti-inflammatory drugs (NSAID) [3].

Currently available treatments for peptic ulcers include antacids (systemic and nonsystemic) and drugs which reduce acid secretion such as $\mathrm{H} 2$ anti-histaminics, proton pump inhibitors, anticholinergics, prostaglandin analogues, ulcer protectives, ulcer healing drugs and anti-H. pylori drugs [4]. These drugs have decreased the morbidity rates, but produce many adverse effects including relapse of the disease, and are often expensive for the poor [5,6]. In light of the above, it is pertinent to study natural products from food/plants as potential anti-ulcer compounds. Due to less side effects compared to synthetic drugs, currently $80 \%$ of the world population depends on plant-derived medicine for the first line of primary health care $[7,8,9]$. Sweet potato (Ipomoea batatas (L.) Lam.) from the family Convolvulaceae, is widely grown in tropical, subtropical \& warm temperate regions and in Asian countries, particularly China. The tubers of Ipomoea batatas are commonly known as sweet potato. Sweet potato has been reported to possess anti oxidant, anti-diabetic, wound healing, anti-bacterial, and anti-mutagenic properties $[10,11,12]$.

\section{MATERIALS AND METHODS:}

Plant material: Fresh tubers of sweet potato were collected from Colaba market, Colaba, Mumbai and authenticated at the Blatter herbarium, St. Xavier College, Mumbai (Accession no. 47280). Whole tubers were washed with distilled water to remove the exudates from their surfaces.

Drugs and chemicals: Cimetidine was obtained from Unique Chemicals and Pharmaceuticals Ltd., India. Omeprazole was obtained from Dr. Reddy's Laboratories, India. Epinephrine, reduced glutathione and oxidized glutathione, were obtained Sigma Aldrich Chemicals, Germany. Thiobarbituric acid (TBA) and trichloroacetic acid (TCA) were obtained from Himedia Laboratories, Mumbai, India. All other chemicals were obtained from local sources and were of analytical grade.

Extraction: Tuber Extract (TE): The tubers of sweet potato were size reduced, dried at $60^{\circ} \mathrm{C}$ and extracted with methanol by using a soxlet apparatus at $60^{\circ} \mathrm{C}$. The extract was collected and put 
on a water bath to evaporate the methanol; the extract was further dried in vacuum oven. The dried TE was dissolved in water to get a clear red solution, which used for administration.

Experimental animals: Wistar albino rats (150-200 g) of either sex were used. They were housed in clean polypropylene cages under standard conditions of humidity $(50 \pm 5 \%)$, temperature $\left(25 \pm 2^{\circ} \mathrm{C}\right)$ and light $(12 \mathrm{~h} \mathrm{light} / 12 \mathrm{~h}$ dark cycle) and fed with a standard diet (Amrut laboratory animal feed, Pune, India) and water ad libitum. All animals were handled with humane care. Experimental protocols were reviewed and approved by the Institutional Animal Ethics Committee (Animal House Registration No.25/1999/CPCSEA) and conform to the Indian National Science Academy Guidelines for the Use and Care of Experimental Animals in Research.

Acute toxicity study (ALD50): Acute toxicity studies were carried out on Wistar rats by the oral route at dose levels up to $2000 \mathrm{mg} / \mathrm{kg}$ of the tuber extract of Ipomoea batatas as per the OECDguidelines No.402.

Anti-ulcer activity: Adult Wistar albino rats of either sex weighing 180-200 $\mathrm{g}$ were used for the study. The effects of the tuber extract were evaluated on cold stress and aspirin induced ulcer models in rats. Cimetidine was used as a standard drug for the cold stress induced ulcer model and omeprazole was used as a standard drug for the aspirin induced ulcer model for comparing the anti-ulcer potential of the extract.

\section{COLD RESTRAINT MODEL (stress induced ulceration) [13]}

Albino Wistar rats of either sex were divided into five groups with six animals in each group as follows:

Group I: Control (untreated) group.

Group II: Stress control group

Group III: Standard treatment group (cimetidine $100 \mathrm{mg} / \mathrm{kg}$ )

Group IV: Test treatment group ( TE $400 \mathrm{mg} / \mathrm{kg}$ )

Group V: Test treatment group ( TE $800 \mathrm{mg} / \mathrm{kg}$ )

Stress was induced by immobilizing the animals in a cylindrical cage $(19.5 \mathrm{~cm}$ length, $6.5 \mathrm{~cm}$ diameter), at $4^{\circ} \mathrm{C}$ for 1 hour daily for 7 days. On the $7^{\text {th }}$ day animals were humanely sacrificed using ether and the stomachs were excised. Ulcers were observed under magnifying glass for measuring the area of ulcers and the ulcer index was calculated.

The stomachs that were excised from the control and treated groups were weighed and chilled in ice cold saline after evaluation of the above parameters, 10\% stomach homogenate was prepared in $\mathrm{KCl}(1.15 \% \mathrm{w} / \mathrm{v})$ which was further utilized for estimation of various parameters like lipid peroxidation (LPO) and endogenous antioxidants like glutathione (GSH), superoxide dismutase (SOD), catalase (CAT), glutathione peroxidase (GPx) and glutathione reductase (GR).

\section{ASPIRIN INDUCED GASTRIC ULCERATION [14, 15]}

Albino Wistar rats of either sex were divided into five groups with six animals in each group as follows: 
Group I: Control (untreated) group

Group II: Toxicant group (aspirin $200 \mathrm{mg} / \mathrm{kg}$ )

Group III: Standard treatment group (omeprazole $20 \mathrm{mg} / \mathrm{kg}$ )

Group IV: Test treatment group ( TE $400 \mathrm{mg} / \mathrm{kg}$ )

Group V: Test treatment group ( TE $800 \mathrm{mg} / \mathrm{kg}$ )

All rats were fasted for 24 hours but excess water was allowed. The standard drug (omeprazole $20 \mathrm{mg} / \mathrm{kg}$ ) and the test drugs (TE 400 and $800 \mathrm{mg} / \mathrm{kg}$ ) were administered orally to the respective groups. One hour after their pretreatment, all animals were gavaged with aspirin $(200 \mathrm{mg} / \mathrm{kg}$ ). After 4 hours, they were humanely sacrificed by using diethyl ether. The numbers of ulcer spots in the glandular portion of the stomach were counted in both normal control and drug treated animals and the ulcer index was calculated. The stomach was further tested for LPO, GSH, SOD, CAT, GPx and GR.

\section{Following parameters were evaluated for anti-ulcer activity}

1) Ulcer assessment [16]

The stomachs were harvested, opened along the greater curvature and the mucosa was exposed for macroscopic evaluation. The ulcerated area was assessed and the ulcer index (UI, $\mathrm{mm}^{2}$ ) was calculated as the arithmetic mean for each treatment. Following the analysis, the mucosal layer was blotted dry and scraped off the underlying muscularis externa and serosa.

2) Mean scoring [16]

A yardstick for ulceration was made as follows:

00: Normal colouration

0.5: Red colouration

1: Spot ulcers

1.5: Haemorrhagic streaks

2: Ulcers $>3 \mathrm{~mm}$ but $<5 \mathrm{~mm}$

3: Perforation

3) Ulcer index [17]

Ulcer index was calculated as

Ulcer index $=10 / x$

Where $\mathrm{x}=$ Total mucosal area/Total ulcerated area.

\section{DETERMINATION OF BIOCHEMICAL PARAMETERS:}

Estimation of antioxidants and protein content in gastric tissue: The GSH level in the stomach tissue was determined according to the method of Ellman [18]. Gastric SOD activity was estimated by the method of Sun and Zigman [19]. CAT activity was estimated by the Clairborne et al method [20]. GPx estimation was carried out using the method of Rotruck et al [21]. GR activity was determined by using the method of Mohandas et al [22]. The protein content of the gastric tissue was determined by the Folin Lowry Method using bovine serum albumin as standard [23].

Estimation of thiobarbituric acid reactive substances (TBARS) in gastric tissue [LPO]: The quantitative estimation of LPO was done by determining the concentration of Thiobarbituric 
Acid Reactive Substances (TBARS) in gastric tissue using the method of Ohkawa \& Yagi [24]. The amount of malondialdehyde (MDA) formed was quantified by reaction with TBA and used as an index of lipid peroxidation. The results were expressed as nmol of MDA/mg protein using molar extinction coefficient of the chromophore $\left(1.56 \times 10^{-5} / \mathrm{M} / \mathrm{cm}\right)$ and $1,1,3,3-$ tetraethoxypropane as standard.

Statistical analysis: The results of anti-ulcer activity are expressed as mean \pm SEM. Results were statistically analyzed using one-way ANOVA, followed by the Tukey-Kramer post test for individual comparisons. $\mathrm{P}<0.05$ were considered to be significant.

\section{RESULTS:}

The images of the stomachs of the groups viz., Control, Standard and treatment groups ( 2 dose levels of TE) in CRS (Figures 1-4) and aspirin-induced gastric lesion models (Figures 5-8) are shown below.

\section{Observations of ulcers in cold restraint model}

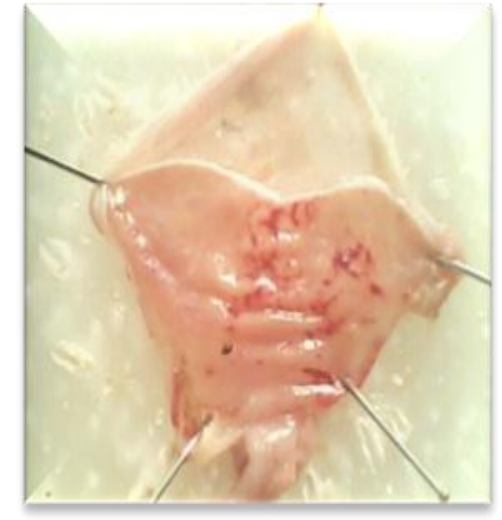

Figure 1. Stress control group

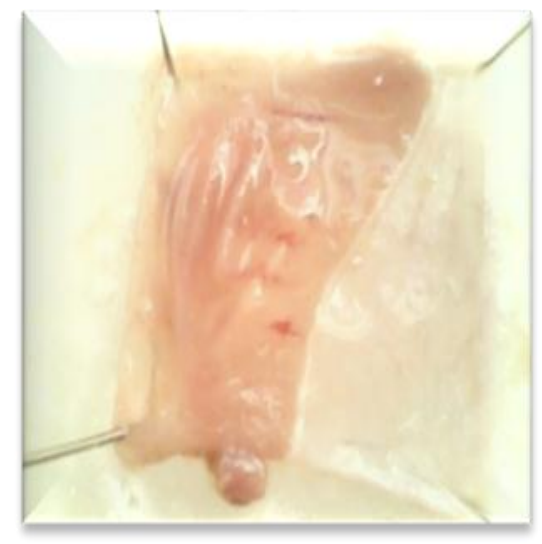

Figure 3. TE $400 \mathrm{mg} / \mathrm{kg}$ group

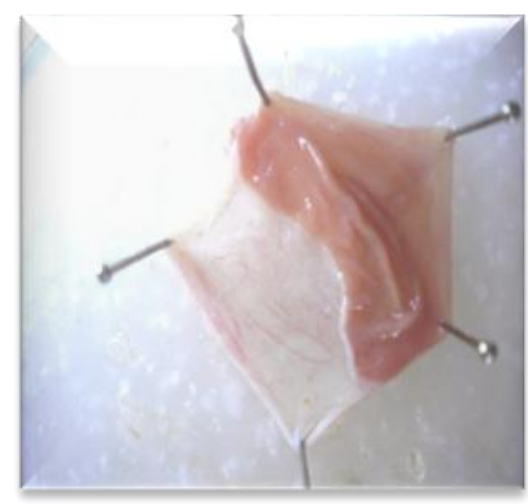

Figure 2. Standard (Cimetidine $100 \mathrm{mg} / \mathrm{kg}$ ) group

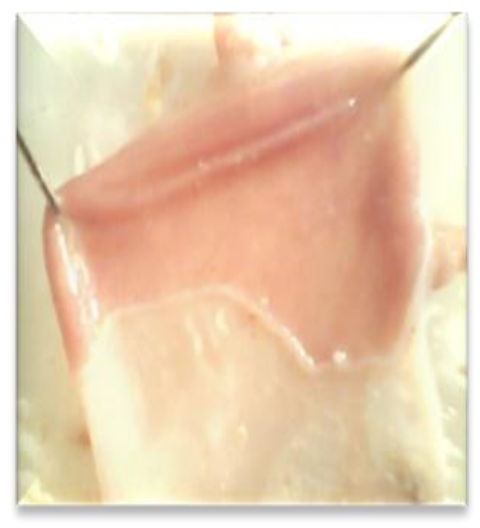

Figure 4. TE $800 \mathrm{mg} / \mathrm{kg}$ group 


\section{Observations of ulcers in aspirin-induced mucosal lesions}

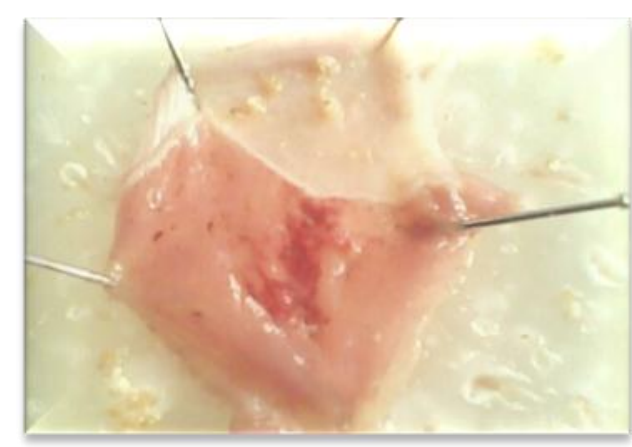

Figure 5. Toxicant (aspirin $200 \mathrm{mg} / \mathrm{kg}$ ) group

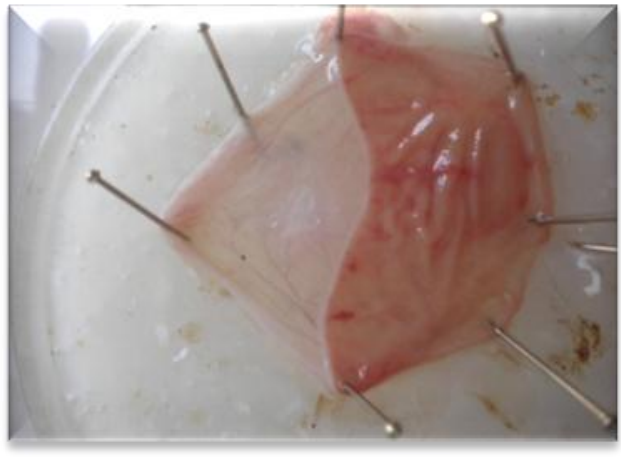

Figure 7. TE $400 \mathrm{mg} / \mathrm{kg}$ group

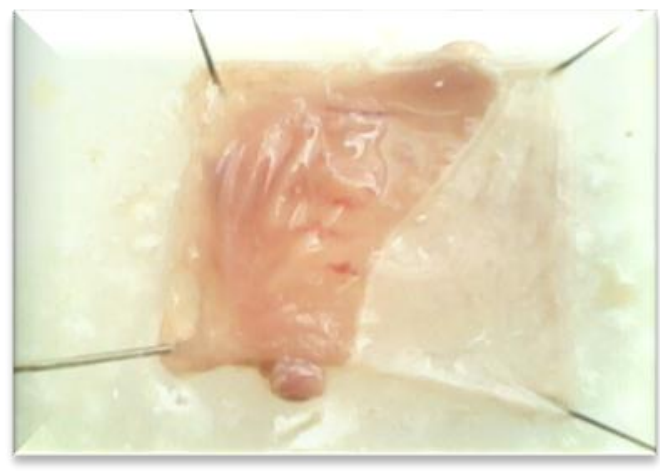

Figure 6. Standard (omeprazole $20 \mathrm{mg} / \mathrm{kg}$ ) group

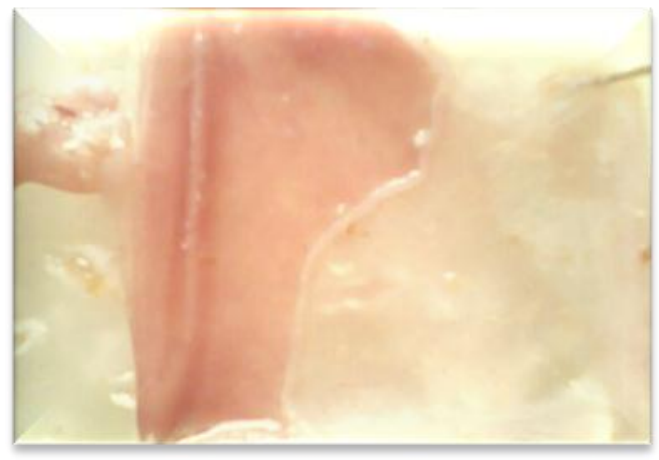

Figure 8. TE $800 \mathrm{mg} / \mathrm{kg}$ group

Marked ulcers along with hemorrhagic streaks and mucosal damage were seen in the images of the toxicant group in the CRS (Figure 1) and the aspirin-induced gastric lesion model (Figure 5). The images of the treatment groups showed signs of recovery from stress and ulcers and also provided supportive evidence for the biochemical analysis (Figures 3-4 and 7-8).

Effect of TE on ulcer index and percentage lesion inhibition: The anti-ulcer activity of TE in CRS and aspirin-induced gastric lesion models is reported in Tables 1 and 2 respectively. TE treatment produced a significant reduction of the ulcer index (U.I.) (TE $400 \mathrm{mg} / \mathrm{kg}, P<0.05$; TE 800 and standard, $P<0.01$ ) when compared with the stress control group in the CRS model and the toxicant group in the aspirin induced ulcer model. The percentage lesion inhibition for TE 400 and TE $800 \mathrm{mg} / \mathrm{kg}$ was $23.13 \%$ and $38.48 \%$, respectively in the CRS induced ulcer model and $43.71 \%$ and $64.99 \%$, respectively in the aspirin-induced gastric lesion model.

Table 1. Effect of TE on ulcer parameters in cold restraint model in rats

\begin{tabular}{|l|l|l|c|}
\hline Treatment Groups/Doses & Mean Ulcer Score & Ulcer Index & \% Inhibition \\
\hline Stress Control Group & $2.917 \pm 0.41$ & $0.9848 \pm 0.04$ & - \\
\hline
\end{tabular}




\begin{tabular}{|l|l|l|l|}
\hline $\begin{array}{l}\text { Test treatment group } \\
(\mathrm{TE} 400 \mathrm{mg} / \mathrm{kg})\end{array}$ & $1.617 \pm 0.08^{\mathrm{a}}$ & $0.7570 \pm 0.03^{\mathrm{a}}$ & 23.13 \\
\hline $\begin{array}{l}\text { Test treatment group } \\
(\mathrm{TE} 800 \mathrm{mg} / \mathrm{kg})\end{array}$ & $1.33 \pm 0.27^{\mathrm{b}}$ & $0.5908 \pm 0.02^{\mathrm{b}}$ & 38.48 \\
\hline $\begin{array}{l}\text { Standard Cimetidine } \\
100 \mathrm{mg} / \mathrm{kg} \text { ) group. }\end{array}$ & $1.050 \pm 0.4463^{\mathrm{b}}$ & $0.359 \pm 0.053^{\mathrm{b}}$ & 36.90 \\
\hline
\end{tabular}

Values are mean $\pm \mathrm{SEM} ; N=6$ in each group

$P$ values : ${ }^{a}<0.05$ when experimental groups compared with Stress Control

${ }^{\mathrm{b}}<0.01$ when experimental groups compared with Stress Control

Table 2. Effect of TE on ulcer parameters in aspirin induced ulcer model in rats.

\begin{tabular}{|l|l|l|l|}
\hline Treatment Groups / Doses & Mean ulcer score & Ulcer Index & \% Inhibition \\
\hline \multicolumn{1}{|c|}{ Toxicant group } & $2.583 \pm 0.271$ & $0.9257 \pm 0.033$ & - \\
\hline $\begin{array}{l}\text { Test treatment group } \\
(\mathrm{TE} 400 \mathrm{mg} / \mathrm{kg})\end{array}$ & $1.586 \pm 0.374^{\mathrm{a}}$ & $0.5211 \pm 0.189^{\mathrm{a}}$ & 43.71 \\
\hline $\begin{array}{l}\text { Test treatment group } \\
(\mathrm{TE} 800 \mathrm{mg} / \mathrm{kg})\end{array}$ & $1.00 \pm 0.258^{\mathrm{b}}$ & $0.324 \pm 0.014^{\mathrm{b}}$ & 64.99 \\
\hline $\begin{array}{l}\text { Standard group } \\
\text { (omeprazole } 20 \mathrm{mg} / \mathrm{kg}) .\end{array}$ & $0.833 \pm 0.210^{\mathrm{b}}$ & $0.3083 \pm 0.030^{\mathrm{b}}$ & 66.99 \\
\hline
\end{tabular}

Values are mean $\pm \mathrm{SEM} ; N=6$ in each group

$P$ values : ${ }^{a}<0.05$ when experimental groups compared with Toxicant Control

${ }^{\mathrm{b}}<0.01$ when experimental groups compared with Toxicant Control

Effect of TE on the gastric tissue levels of GSH, TBARS and activities of antioxidant enzymes SOD, CAT, GPx and GR in ulcer models: In order to determine the effect of TE on oxidative stress induced in various ulcer models, the levels of GSH, TBARS and activities of SOD, CAT, GPx and GR were measured in gastric tissue. Ulcer induction in both the models was associated with marked reduction in the level of GSH, and activities of SOD, CAT, GPx \& GR, and an increase in the level of TBARS. Treatment with TE produced a significant increase in the level of GSH and activities of SOD, CAT, GPx \& GR, and a significant decrease in the level of TBARS in the cold stress and aspirin models (Tables 3 and 4).

Table 3. Effect of TE on stomach GSH, TBARS, SOD, CAT, GPx and GR in cold restraint model in rats

\begin{tabular}{llllcc}
\hline $\begin{array}{l}\text { Biochemical } \\
\text { parameters }\end{array}$ & $\begin{array}{l}\text { Group I } \\
\text { Normal } \\
\text { Control }\end{array}$ & $\begin{array}{l}\text { Group II } \\
\text { Stress } \\
\text { Control }\end{array}$ & $\begin{array}{l}\text { Group III } \\
\text { TE } \\
\mathbf{( 4 0 0 ~} \mathbf{~ g / / k g})\end{array}$ & $\begin{array}{l}\text { Group IV } \\
\text { TE }\end{array}$ & $\begin{array}{l}\mathbf{8 0 0} \mathbf{~} \mathbf{~ G r o u p ~} \mathbf{k g}) \\
\text { Cimetidine } \\
\mathbf{( 1 0 0 m g / k g )}\end{array}$ \\
\hline $\begin{array}{l}\text { GSH }(\mu \mathrm{mol} / \mathrm{mg} \\
\text { protein) }\end{array}$ & $2.18 \pm 0.04$ & $\begin{array}{l}1.68 \pm \\
0.07^{\mathrm{a}}\end{array}$ & $1.72 \pm 0.08$ & $2.1 \pm 0.07^{\mathrm{c}}$ & $2.15 \pm 0.06^{\mathrm{c}}$ \\
$\begin{array}{l}\text { TBARS (nmol } \\
\text { MDA/mg protein) }\end{array}$ & $0.50 \pm 0.02$ & $\begin{array}{l}0.95 \pm \\
0.03^{\mathrm{a}}\end{array}$ & $0.71 \pm 0.02^{\mathrm{d}}$ & $0.67 \pm 0.02^{\mathrm{d}}$ & $0.68 \pm 0.01^{\mathrm{d}}$ \\
\hline
\end{tabular}




\begin{tabular}{|c|c|c|c|c|c|}
\hline $\begin{array}{l}\text { SOD } \\
\text { (U/mg protein) }\end{array}$ & $\begin{array}{l}36.04 \pm \\
0.15\end{array}$ & $\begin{array}{l}11.96 \pm \\
1.40^{\mathrm{a}}\end{array}$ & $26.83 \pm 2.8^{\mathrm{d}}$ & $34.26 \pm 0.36^{\mathrm{d}}$ & $31.27 \pm 0.8^{d}$ \\
\hline $\begin{array}{l}\text { CAT } \\
\text { (U/mg protein) }\end{array}$ & $\begin{array}{l}17.58 \pm \\
0.37\end{array}$ & $8.44 \pm 0.65^{\mathrm{a}}$ & $11.72 \pm 0.67^{\mathrm{b}}$ & $15.68 \pm 0.99^{\mathrm{d}}$ & $15.28 \pm 0.63^{\mathrm{d}}$ \\
\hline $\begin{array}{l}\text { GPx } \\
\text { (U/mg protein) }\end{array}$ & $\begin{array}{l}12.74 \pm \\
0.23\end{array}$ & $9.83 \pm 0.23^{\mathrm{a}}$ & $11.78 \pm 0.48^{\mathrm{c}}$ & $14.50 \pm 0.41^{\mathrm{d}}$ & $13.04 \pm 0.31^{\mathrm{d}}$ \\
\hline $\begin{array}{l}\text { GR } \\
\text { (U/mg protein) }\end{array}$ & $\begin{array}{l}115.1 \pm \\
5.77\end{array}$ & $\begin{array}{l}48.65 \pm \\
2.01^{\mathrm{a}}\end{array}$ & $97.75 \pm 4.54^{\mathrm{c}}$ & $113.27 \pm 6.54^{\mathrm{d}}$ & $106 . .89 \pm 17.17^{\circ}$ \\
\hline
\end{tabular}

Values are mean $\pm \mathrm{SEM} ; N=6$ in each group

$P$ values : ${ }^{a}<0.001$ when Stress Control group compared with Normal Control group

${ }^{\mathrm{b}}<0.05,{ }^{\mathrm{c}}<0.01,{ }^{\mathrm{d}}<0.001$ when experimental groups compared with Stress Control group

1 unit of $\mathrm{CAT}=\mu \mathrm{mol} \mathrm{H}_{2} \mathrm{O}_{2}$ consumed $/ \mathrm{min} / \mathrm{mg}$ protein

1 unit of GPX $=\mu \mathrm{g}$ GSH utilized $/ \mathrm{min} / \mathrm{mg}$ protein

1 unit of $\mathrm{GR}=\mathrm{nmol} \mathrm{NADPH}$ oxidized $/ \mathrm{min} / \mathrm{mg}$ protein

Table 4. Effect of TE on stomach GSH, TBARS, SOD, CAT, GPx and GR in aspirin induced ulcer model in rats.

\begin{tabular}{lllccc}
\hline $\begin{array}{l}\text { Biochemical } \\
\text { parameters }\end{array}$ & $\begin{array}{l}\text { Group I } \\
\text { Normal } \\
\text { Control }\end{array}$ & $\begin{array}{l}\text { Group II } \\
\text { Toxicant }\end{array}$ & $\begin{array}{l}\text { Group III } \\
\text { TE }(\mathbf{4 0 0} \mathbf{~ m g} / \mathbf{k g})\end{array}$ & $\begin{array}{l}\text { Group IV } \\
\text { TE }(\mathbf{8 0 0} \mathbf{~ m g} / \mathbf{k g})\end{array}$ & $\begin{array}{l}\text { Group V } \\
\text { (omeprazole 20 } \\
\mathbf{~ m g / k g})\end{array}$ \\
\hline $\begin{array}{l}\text { GSH }(\mu \mathrm{mol} / \mathrm{mg} \\
\text { protein) }\end{array}$ & $1.52 \pm 0.06$ & $0.97 \pm 0.007^{\mathrm{a}}$ & $1.16 \pm 0.03^{\mathrm{c}}$ & $1.34 \pm 0.02^{\mathrm{d}}$ & $1.30 \pm 0.01^{\mathrm{d}}$ \\
$\begin{array}{l}\text { TBARS }(\mathrm{nmol} \\
\text { MDA/mg } \\
\text { protein) }\end{array}$ & $0.56 \pm 0.06$ & $1.10 \pm 0.03^{\mathrm{a}}$ & $0.90 \pm 0.01^{\mathrm{d}}$ & $0.76 \pm 0.01^{\mathrm{d}}$ & $0.77 \pm 0.08^{\mathrm{d}}$ \\
$\begin{array}{l}\text { SOD } \\
\text { (U/mg protein) }\end{array}$ & $48.28 \pm 0.05$ & $21.83 \pm 0.08^{\mathrm{a}}$ & $41.14 \pm 0.34^{\mathrm{d}}$ & $44.76 \pm 0.36^{\mathrm{d}}$ & $46.40 \pm 0.29^{\mathrm{d}}$ \\
$\begin{array}{l}\mathrm{CAT} \\
(\mathrm{U} / \mathrm{mg} \text { protein) }\end{array}$ & $8.15 \pm 0.076$ & $4.18 \pm 0.988^{\mathrm{a}}$ & $5.88 \pm 0.816^{\mathrm{b}}$ & $7.12 \pm 0.040^{\mathrm{c}}$ & $7.62 \pm 0.150^{\mathrm{c}}$ \\
$\begin{array}{l}\mathrm{GPx} \\
(\mathrm{U} / \mathrm{mg} \text { protein) }\end{array}$ & $8.59 \pm 0.15$ & $5.89 \pm 0.36^{\mathrm{a}}$ & $7.10 \pm 0.24^{\mathrm{b}}$ & $10.86 \pm 0.41^{\mathrm{d}}$ & $10.78 \pm 0.2^{\mathrm{d}}$ \\
& & & & & \\
$\begin{array}{l}\text { GR } \\
(\mathrm{U} / \mathrm{mg} \text { protein) }\end{array}$ & $56.44 \pm 0.87$ & $31.59 \pm 0.75^{\mathrm{a}}$ & $39.50 \pm 3.33^{\mathrm{b}}$ & $51.57 \pm 0.63^{\mathrm{d}}$ & $51.00 \pm 0.90^{\mathrm{d}}$ \\
\hline
\end{tabular}

Values are mean \pm SEM; $N=6$ in each group

$P$ values : ${ }^{\text {a }}<0.001$ when Toxicant Control compared with Normal Control

${ }^{\mathrm{b}}<0.05,{ }^{\mathrm{c}}<0.01 \&{ }^{\mathrm{d}}<0.001$ when experimental groups compared with Toxicant Control

1 unit of $\mathrm{CAT}=\mu \mathrm{mol} \mathrm{H}_{2} \mathrm{O}_{2}$ consumed $/ \mathrm{min} / \mathrm{mg}$ protein

1 unit of GPX $=\mu \mathrm{g}$ GSH utilized $/ \mathrm{min} / \mathrm{mg}$ protein

1 unit of $\mathrm{GR}=\mathrm{nmol} \mathrm{NADPH}$ oxidized $/ \mathrm{min} / \mathrm{mg}$ protein

\section{DISCUSSION:}

Tuber extract (TE) of Ipomoea batatas did not show any toxic or deleterious effects by oral route up to $2000 \mathrm{mg} / \mathrm{kg}$ indicating low toxicity of the tuber extract at high doses. The $\mathrm{LD}_{50}$ value for 
the tuber extract by oral route could not be determined as no mortality was observed until a dose of $2000 \mathrm{mg} / \mathrm{kg}$.

On preliminary phyto-chemical screening, the tuber extract revealed the presence of phenolic compounds, polysaccharides, saponin glycosides and flavonoids as major compounds that might have contributed to its antioxidant activity.

The present study was carried out to evaluate the ulcer protecting effect of Ipomoea batatas tuber extract in rats where gastric lesions were induced by cold stress and oral administration of aspirin.

Restraint stress has been one of the most popular stressors in experimental medicine. It elicits the purest form of psychological frustration accompanied by vigorous struggling which means muscular exercise [25]. In the cold restraint model, stress in the control group clearly produced a mucosal damage characterized by multiple haemorrhage red bands of different sizes on the glandular stomach. Exposure of the animals to the cold restraint stress may have caused severe imbalance in the normal physiological conditions that might have resulted in a stressful condition leading to ulcers. Pre-treatment with test drugs (TE 400 and TE 800) produced a significant decrease in the intensity of gastric mucosal damage induced by the stress as compared with control. A significant increase in the ulcer index and mean score in the control group was observed, however both the parameters were significantly decreased in the TE 400 and TE 800 treated groups (Table 1). Further, examinations of the stomach images provide supportive evidence for the anti-ulcer activity of TE 400 and TE 800 treated groups which showed signs of recovery from the cold restraint stress induced ulcers (Figures 1-4). The reduction in the ulcer index and mean score may be attributed to the anti-ulcer activity of the tubers due to presence of antioxidants like anthocyanins, phenolic acids (eg, caffeic acid) and vitamin $\mathrm{C}$.

Stress-induced ulcer is probably mediated by the release of histamine [26, 27]. It not only increases gastric secretion, often called the 'aggressive factor', but also causes disturbances of the gastric mucosal microcirculation and an abnormal motility, and reduces mucus production, known as the 'defensive factor'. Moreover, stress-induced ulcers in animal models may be partially or entirely prevented by vagotomy, since increased vagal activity has been suggested as the main factor in stress-induced ulceration. The vagus nerve stimulates stomach acid secretion via interaction of its chemical mediator (acetylcholine) with the muscarinic receptor. The activation of the muscarinic receptor gives rise to sequential events that result in increased gastric acid secretion. These receptors are located on the cell membranes of parietal cells and histamine secretory cells. Therefore, the increase in acid secretion is a consequence of acetylcholine action on the histamine cell and parietal cell activity. Stress-induced ulcers also involve damage by reactive oxygen species (ROS) apart from acid and pepsin related factors [25].

Exposure to cold restraint is a well known intensive stress response wherein both cold exposure and immobilization individually and synergistically are responsible for the generation of reactive oxygen species (ROS) e.g. superoxide anion, hydrogen peroxide, hydroxyl radicals etc. that cause lipid peroxidation, especially in membranes and result in tissue injury.

Elevation in the levels of end products of lipid peroxidation in stress control rat stomachs was observed. The increase in MDA levels in the stomach suggests enhanced peroxidation leading to tissue damage and failure of the antioxidant defense mechanisms to prevent formation of 
excessive free radicals. Pretreatment with TE 400 and TE 800 significantly reversed these changes (Table 3). Hence, it is likely that the mechanism of ant-ulceration of TE is due to its antioxidant effect.

Reduced glutathione is one of the most abundant non-enzymatic antioxidant biomolecules present in the tissues [28]. Its functions are removal of free oxygen species such as $\mathrm{H}_{2} \mathrm{O}_{2}$, superoxide anions \& alkoxy radicals, maintenance of membrane protein thiols and to act as a substrate for GPx and glutathione $S$ - transferase (GST) [29]. In the present study, stress enhanced the activities of GSH-related enzymes GPx and GST, thereby decreasing the GSH content, whereas treatment with TE reversed these effects (Table 3). It may be understood that the effect of TE may be due to increased synthesis of GSH or by stimulation of GR activity.

Free radical scavenging enzymes such as SOD, CAT \& GPx are known to be the first line cellular defense against oxidative damage, disposing $\mathrm{O}_{2} \& \mathrm{H}_{2} \mathrm{O}_{2}$ before their interaction to form the more harmful hydroxyl $\left(\mathrm{OH}^{\cdot}\right)$ radical [30]. In the present study SOD activity decreased significantly in the stress induced group of animals, which may be due to an excessive formation of superoxide anions (Table 3). These excessive superoxide anions might inactivate SOD and decrease its activity. The activities of the $\mathrm{H}_{2} \mathrm{O}_{2}$ scavenging enzymes CAT \& GPx also decreased significantly in the stress induced group of animals. SOD is an important defense enzyme that catalyzes the dismutation of superoxide anions into $\mathrm{O}_{2}$ and $\mathrm{H}_{2} \mathrm{O}_{2}$ [31]. CAT is a hemeprotein that catalyzes the reduction of $\mathrm{H}_{2} \mathrm{O}_{2}$ to $2 \mathrm{H}_{2} \mathrm{O}$ and $\mathrm{O}_{2}$ and protects the tissue from highly reactive oxygen free radicals \& hydroxyl radicals [32]. GPx, an enzyme with selenium, catalyzes the reduction of $\mathrm{H}_{2} \mathrm{O}_{2}$ and hydroperoxides to non-toxic products with the help of GSH [33]. GR is a cytosolic hepatic enzyme involved in the replenishment of glutathione stores by reduction of oxidized glutathione (GSSG), which is an end product of GPx activity [34]. In the stress induced group of animals, there was a marked reduction in GPx activity, leading to reduced availability of substrate for GR, thereby decreasing the activity of GR. Pretreatment with TE 400 and TE 800 significantly increased the activity of GR, thus accelerating the utilization of GSSG to form GSH and enhancing the detoxification of reactive metabolites by conjugation with GSH [35] (Table 3).

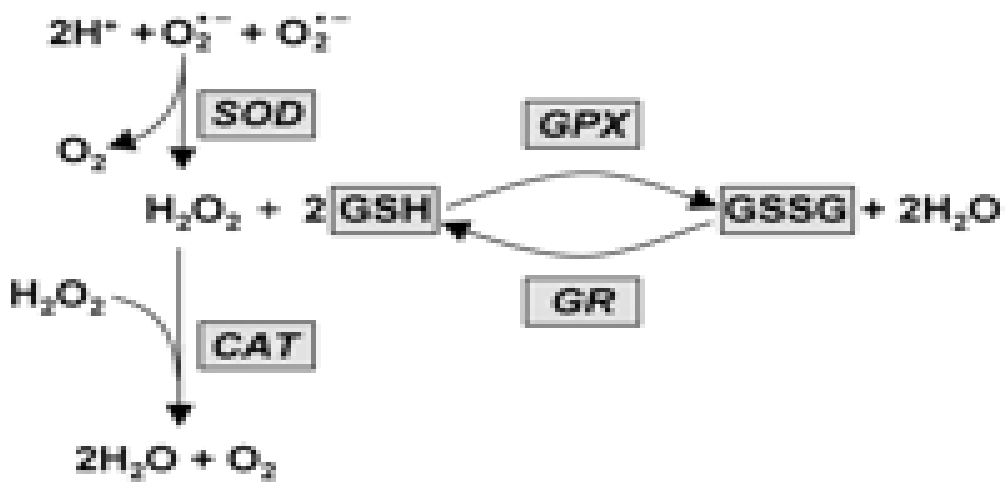

In this study SOD, CAT, GPx \& GR activities were significantly elevated by administration of TE to treatment rats, suggesting that it has the ability to restore these enzymes' activities in stress control rats. 
In conclusion, the anti-ulcerative effect of TE against cold stress induced ulcer in rats appears to be related to the inhibition of lipid peroxidative processes and to the prevention of GSH depletion. Furthermore, it may be stated that TE exerts its antioxidant activity by a dual action - by enzymatic as well as non-enzymatic pathways.

Nonsteroidal anti-inflammatory drugs (NSAIDs) such as aspirin have the ability to cause gastroduodenal ulceration and this effect is related to the ability of these agents to suppress prostaglandin synthesis $[36,37,38]$. In the stomach, prostaglandins play a vital protective role, stimulating the secretion of bicarbonate and mucus, maintaining mucosal blood flow and regulating mucosal cell turnover and repair. Thus, the suppression of prostaglandin synthesis by NSAIDs results in increased susceptibility to mucosal injury and gastroduodenal ulceration [39]. One of the mechanisms by which aspirin damages the gastric mucosa is the increased production of NO due to the over expression of iNOS [40]. NO is a mediator not only of gastrointestinal mucosal defense [41], but also of its damage [42]. It has been shown that different concentrations of $\mathrm{NO}$ have completely opposite effects on the same tissue [43]. In general, the mucosal and endothelial NOS isoforms produce low amounts of NO. However, the high quantity of NO produced by iNOS damages the epithelium [43, 44]. The excessive release of NO from gastric epithelial cells induced by aspirin has been reported to exert detrimental effects [45].

In this study, exposure of the animals to aspirin may have caused severe ulcerogenic effects, as aspirin is known to increase gastric acid secretion which is involved in the formation of aspirin-induced mucosal lesions.

However, gastric protection was observed by TE 400 and TE 800 in aspirin induced gastric ulcers through parameters like mean score and ulcer index (Table 2). The gastroprotective activity of the TE 400 and TE 800 seems to be related to a reduction in the damage to the mucosa induced by free radicals and this activity may be due to its antioxidant action. These findings could be efficiently corroborated with the images of the aspirin induced animal group when compared with the TE 400 and TE 800 treated animal groups (figures 5-8).

Aspirin induced ulcer group of animals showed an increase in MDA level (Table 4) and a decrease in GSH level (Table 4), as well as SOD, CAT, GPx and GR activities which was reversed in TE 400 and TE 800 treatment groups (Table 4) probably by exhibiting a similar mechanism as explained in cold restraint model.

\section{CONCLUSION:}

In conclusion, this study demonstrates that the tubers of Ipomoea batatas possess a potent ulcer healing effect, which appears to be related to the free radical scavenging activity of the phyto constituents, and their ability to inhibit lipid peroxidative processes. The present study, thus, aims to highlight the health benefits of sweet potato, establish it as a potent "functional food" and promote its use as a vegetable to enrich people's diets.

Competing interests: The authors declare that they have no competing interests.

Authors' contributions: Vandana Panda, conceived, designed, co-ordinated and supervised the study and the writing of the manuscript. Madhav Sonkambale, initiated the study, carried out the 
experimental, performed statistical analysis and drafted the manuscript. All authors read and approved the final manuscript.

Acknowledgement: We would like to thank Glenmark Pharmaceuticals Ltd. Mahape, Navi Mumbai for providing animals for this research work.

\section{REFERENCES:}

1. Cullen D J, Hawkey G M, Greenwood D C: Peptic ulcer bleeding in the elderly: relative roles of Helicobacter pylori and non-steroidal anti-inflammatory drugs. Gut 1997, 41 (4): 459-62.

2. Mohan H: Textbook of Pathology, Jaypee Brothers Medical publishers (P) Ltd, New Delhi; 2002, 4 : 526-535.

3. Berenguer L M, S'anchez A, Qu'ilez M: Protective and antioxidant activity of Rhizophoro Mangle L. against NSAID'S induced gastric ulcer. J. Ethanopharmacol 2006, 103:194-200.

4. Rang \& Dale: The textbook of Pharmacology, An imprint of Elsevier. 2003, 5: 244-259.

5. Srikanta BM, Siddaraju MN, Dharmesh SM: A novel phenol-bound pectic polysaccharide from Decalepis hamiltonii with multi-step ulcer preventive activity. World J Gastroenterol 2007, 13(39): 5196-207.

6. Maitya B, Chattopadhyay S: Natural Antiulcerogenic Agents: An Overview. Current Bioactive Compounds 2008, 4: 225-44.

7. Samy RP, Gopalakrishnakone P: Current status of herbal and their future perspectives. Nature Precedings 2007: 1-13.

8. Cordell GA, Plants in Drug Discoverv - Creating a New Vision. In: Tan BK, Bay BH, Zhu YZ. Novel compounds from natural products in the new Millennium potential and challenges, National university of Singapore: World Scientific publishing; 2004. pp1-7.

9. Verma S, Singh SP: Current and future status of herbal medicines. Veterinary World 2008, 1(11): 347-50.

10. Scott G: Transforming traditional food crops: product development for roots and tubers. In: Scott GJ, Wiersema S, Ferguson PI (Eds.), Product Development for Roots and Tuber Crops, vol. 1, Asia. International Potato Center (CIP), Lima, Peru; 1992:3-20.

11. Hayase F, Kato H: Antioxidative components of sweet potatoes. J. Nutritional Science and Vitaminology 1984, 30: 37-46.

12. Kusano S, Abe H: Antidiabetic activity of white skinned sweet potato (Ipomoea batatas L.) in obese Zucker fatty rats. Biological and Pharmaceutical Bulletin 2000, 23: 23-26.

13. Deore S L: Screening of anti stress properties of Chlorophytum borivilianum tuber. Pharmacology online 2009, 1: 320-328.

14. Singh S, Majumdar D K: Evaluation of the gastric antiulcer activity of fixed oil of Ocimum sanctum (Holy Basil). J. Ethnopharmacol 1999, 65:13-19.

15. Sairam K, Rao Ch.V, Dora Babu M, Vijay Kumar K, Agrawal VK, Goel RK: Antiulcerogenic effect of methanolic extract of Emblica officinalis: an experimental study. J. of Ethnopharmacology 2002, 82: 1-9. 
16. Malairajan P, Gopalkrishnan G, Nrasimhan S, Jessi Kala Veni K, Kavimani S: Anti-ulcer activity of crude alcoholic extract of Toona ciliata Roemer (heart wood). J. Ethanopharmacol 2007, 110: 348-357.

17. Ganguly A K, Bhatnagar O P: Effect of bilateral adrenalotomy on production of restraint ulcers in stomach of albino rats. Canadian J. of Physiology and Pharmacology 1973, 51:748-750.

18. Ellman G L, Tissue sulphydryl groups. Arch Biochem Biophys 1959, 82: 70-77.

19. Sun M, Zigman S: An improved spectrophotometric assay for superoxide dismutase based on epinephrine auto-oxidation. Anal. Biochem 1978, 90 (1): 81-89.

20. Clairborne A: Catalase Activity In: Greenwald RA CRS Handbook of Methods in Oxygen Radical Research Boca Raton, CRS Press 1985: 283-284

21. Rotruck J T, Pope A L, Ganther H E, Hofeman D G, Hoekstra W G: Selenium: Biochemical role as a component of Glutathione peroxidase. Science 1973, 179: 588-590.

22. Mohandas J, Marshal J J, Duggin G G, Harvasth J S,: Low activities of Glutathionerelated enzymes as factors in the genesis of urinary bladder cancer. Cancer Res. 1984, 44: 5086-91.

23. Lowry O H, Rosebrough N J, Farr A L, Randall R J: Protein Estimation with the Folinphenol reagent. J. Biol. Chem. 1951, 193: 265-275.

24. Ohkawa H, Oshishi N, Yagi K: Assay of lipid peroxidation in animal tissue by thiobarbituric acid reaction. Anal. Biochem. 1979, 95:351-58.

25. Bhattacharya A, Ghosal S, Bhattacharya S K: Anti-oxidant effect of Withania somnifera glycowithanolides in chronic foot shock stress-induced perturbations of oxidative free radical scavenging enzymes and lipid peroxidation in rat frontal cortex and striatum. $\mathbf{J}$. Ethnopharmacol 2001, 74: 1-6.

26. Michael N P, Charles T R: Stressful life events, acid hypersecretion and ulcer disease. Gastroenterology 1983, 84:114-119.

27. Brodie D A Q, Hanson H M: A study of the factors involved in the production of gastric ulcer by the restraint technique. Gastroenterology 1960, 38:353-360.

28. Meister A: New aspects of glutathione biochemistry and transport selective alteration of glutathione metabolism. Nutr. Rev. 1984, 42: 397-400.

29. Townsend DM, Tew KD, Tapiero H: The importance of glutathione in human disease. Biomed. Pharmacother. 2003, 57:144-155.

30. Lil JL, Stantman FW, Lardy HA. Antioxidant enzyme systems in rat liver and skeletal muscle. Arch. Biochem. Biophys.1988; 263:150-160.

31. Bannister J, Bannister W: Aspects of the structure, function and application of superoxide dismutase. CRC Crit Rev Biochem 1987, 22 (2): 111-80.

32. Zamocky M, Koller F: Understanding the structure and function of catalases clues from molecular evolution and in vitro mutagenesis. Prog Biophy. Mol Bio 1999, 72 (1): 1966

33. Bruce A, Freeman D, James C: Biology of disease-free radicals and tissue injury. Lab. Invest. 1982, 47: 412-426.

34. Manneersk B: The enzymes of glutathione metabolism: an overview. Biochem Soc Trans 1987, 15 (4):717- 8. 
35. Naik S, Panda V: Hepatoprotective effect of Ginkgoselect Phytosome ${ }^{\circledR}$ in rifampicin induced liver injurym in rats: Evidence of antioxidant activity, Fitoterapia 2008, 79 (6):439- 445.

36. Takeuchi K, Ueki S, Tanaka H: Endogenous prostaglandins in gastric alkaline response in the rat stomach after damage. American J. Physiology 1986, 250: G842-G849.

37. Lichtenberger L M, Romero J J, Dial E J: Surface phospholipids in gastric injury and protection when a selective cyclooxygenase-2 inhibitor (Coxib) is used in combination with aspirin. British J. Pharmacology 2007, 150: 913-919.

38. Wang GZ, Huang GP, Yin GL, Zhou G, Guo, CJ, Xie CG: Aspirin can elicit the recurrence of gastric ulcer induced with acetic acid in rats. Cellular Physiology and Biochemistry 2007, 20: 205-212.

39. Deore A, Sapakal V, Dashputre N, Naikwade N: Antiulcer activity of Garcinia indica linn fruit rinds. J. Applied Pharmaceutical Science 2011, 1 (5): 151-154.

40. Konturek PC, Kania J, Hahn EG, Konturek JW: Ascorbic acid attenuates aspirin-induced gastric damage: role of inducible nitric oxide synthase. J. Physiology and Pharmacology 2006, 57:125-136.

41. Calatayud S, Barrachina D, Espluges JV: Nitric oxide: relation to integrity, injury, and healing of the gastric mucosa. Microsc Res Tech 2001, 53: 325-335.

42. Muscara MN, Wallace JL. Nitric oxide. V: Therapeutic potential of nitric oxide donors and inhibitors. Am. J. Physiol 1999, 276: G1313-G1316.

43. Wallace JL, Miller MJ: Nitric oxide in mucosal defense: a little goes a long way. Gastroenterol 2000, 119: 512-520.

44. Piotrowski J, Slomiany A, Slomiany BL: Activation of apoptotic caspase-3 and nitric oxide synthase- 2 in gastric mucosal injury induced by indomethacin. Scandinavian J. Gastroenterol 1999, 34: 129-134.

45. Whittle BJ: Gastrointestinal effects of nonsteroidal anti-inflammatory drugs. Fundamental \& Clinical Pharmacol 2003, 7: 301-313. 